\section{Conclusion}

Skin trauma is a notable complication of systemic corticosteroid therapy and further threatens the ideal that the doctor should "at least do no harm" by his treatment.

I wish to thank Mr. D. C. Bodenham, Mr. R. T. Routledge, Mr. R. W. Hiles, and Mr. R. W. Pigott for access to their patients and their advice; Mr. J. Lendrum for reading the manuscript;
Mr. L. Banham for his photography; and Mrs. S. Bassett for her clerical assistance.

\section{References}

Grabb, W. C., and Smith, J. W. (editors) (1968). Plastic Surgery, A Concise Guide to Clinical Practice. Boston, Little, Brown.

Griffith, B. H. (1966). Plastic and Reconstructive Surgery and the Transplantation Bulletin, 38, 202.

Mancini, R. E., Stringa, S. G., and Canepa, L. (1960). Fournal of Investigative Dermatology, 34, 393.

Matthews, D. N. (1945). Lancet, 1, 775.

Rook, A., Wilkinson, D. S., and Ebling, F. J. G. (1968). Textbook of Dermatology, vol. 2. Oxford, Blackwell Scientific.

\title{
Gastroenteritis with Necrotizing Enterocolitis in Premature Babies
}

\author{
HARRY STEIN, JOHN BECK, ALBERT SOLOMON, ARTHUR SCHMAMAN
}

British Medical fournal, 1972, 2, 616-619

\section{Summary}

Eleven premature babies developed necrotizing enterocolitis in an epidemic of gastroenteritis and salmonella infection. This occurred in one of two premature baby wards over a period of 10 weeks. All afiected babies had severe gastroenteritis and six had salmonella infection. No cases of necrotizing enterocolitis occurred in the unafiected ward during the same period. All other possible factors which might have predisposed to necrotizing enterocolitis occurred with equal frequency in both wards.

There seems little doubt that infection was the signifcant factor in the pathogenesis.

\section{Introduction}

Necrotizing enterocolitis in neonates has aroused great interest in the past decade. Its increasing frequency is thought to be due to the fact that many neonates, particularly premature babies, who would previously have succumbed are now surviving (Fetterman, 1971). An association with exchange transfusion is well described (Castor, 1968; Corkery et al., 1968; Orme and Eades, 1968; Beck et al., 1971). For the rest a multiplicity of associations occurs. It seems to be more common in premature babies (Rossier, et al., 1959; Berdon et al., 1964; Mizrahi et al., 1965) and particularly when they have suffered from asphyxia, apnoeic attacks, hyaline membrane disease, or hypothermia. These stress conditions may give rise to intestinal ischaemia with devitalization, infection, and necrosis (Lloyd, 1969; Stevenson et al., 1969; Fetterman, 1971). Stasis of intestinal contents seems important in some cases. To many authors the role of infection seems paramount in the pathogenesis (Blanc, 1952; Waldhausen et al., 1963; Mizrahi et al., 1965). This has been thought to act by promoting a Shwartzman reaction (Rossier et al., 1959; Hermann, 1965). The evidence for infection is somewhat tenuous, and local infection and particularly infective diarrhoea are considered rare (British

\footnotetext{
Baragwanath Hospital and University of the Witwatersrand and the South African Institute for Medical Research, Johannesburg

HARRY STEIN, M.B., F.R.C.P., Paediatrician

JOHN BECK, M.B., F.R.C.S., Paediatric Surgeon

ALBERT SOLOMON, M.B., M.MED.RAD., Radiologist

ARTHUR SCHMAMAN, M.B., M.R.C.PATH., Pathologist
}

Medical fournal, 1970; Fetterman, 1971). In fact, though bloodstaining of stools is a common presenting feature there has been very little evidence of a true preceding gastroenteritis and none of salmonella infection.

We report 11 cases in premature babies all associated with frank diarrhoea, and in six of these salmonellae were cultured from the stools. Two of the cases had exchange transfusions.

\section{Subjects}

During a 10-week period in the spring of 1971 an epidemic of gastroenteritis with a high incidence of salmonella cultures, obtained from the stools, occurred in one of two identical premature infant wards at Baragwanath Hospital. This necessitated the closing down of the infected ward. In all, 63 babies had diarrhoea, 22 of whom were infected with either Salmonella thompson or Salmonella johannesburg. Eleven cases of necrotizing enterocolitis occurred in this period; all had diarrhoea and six had proved salmonella infection. During the same period there were no cases at all of necrotizing enterocolitis in the uninfected ward. The babies admitted to the latter ward were identical in all other respects in terms of weight, pregnancy, birth history, and neonatal state to those in the infected ward. The only variable, in fact, was the great discrepancy in the rate of infection.

All babies were Bantu (Negro). Seven were males and four females. All were premature with birth weights ranging from 1,050 to $1,900 \mathrm{~g}$. Nine of the pregnancies were normal, one mother had hypertension, and another was syphilitic. Antenatal care varied a great deal, being adequate in six cases and poor or non-existent in five (Table I). Four babies were born in hospital and the remaining seven "on district"; 10 were vertex presentations and one was breech.

TABLE I-Relevant Aspects of Pregnancy and Delivery

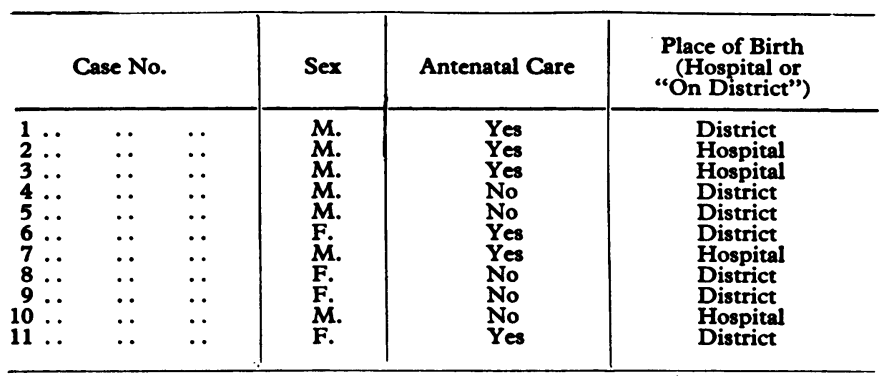


TABLE III-Infective and Definitive Features

\begin{tabular}{|c|c|c|c|c|c|c|c|c|c|c|c|}
\hline & \multirow{2}{*}{\multicolumn{2}{|c|}{$\begin{array}{l}\text { Case } \\
\text { No. }\end{array}$}} & \multirow{2}{*}{$\begin{array}{c}\text { Onset of } \\
\text { Diarrhoea } \\
\text { (Day of } \\
\text { Life) }\end{array}$} & \multirow{2}{*}{$\begin{array}{c}\text { Intravenous } \\
\text { Therapy Began } \\
\text { (Day of } \\
\text { Life) }\end{array}$} & \multirow{2}{*}{$\begin{array}{c}\text { Salmonella } \\
\text { Isolated }\end{array}$} & \multirow{2}{*}{$\begin{array}{c}\text { Onset of } \\
\text { Necrotizing } \\
\text { Enterocolitis } \\
\text { (Day of Life) }\end{array}$} & \multicolumn{4}{|c|}{ Features of Necrotizing Enterocolitis } & \multirow[b]{2}{*}{ Treatment } \\
\hline & & & & & & & Distension & $\begin{array}{l}\text { Bile-stained } \\
\text { Aspirate }\end{array}$ & $\begin{array}{l}\text { Blood-stained } \\
\text { Stools }\end{array}$ & $\begin{array}{l}\text { Oedema of Ab- } \\
\text { dominal Wall }\end{array}$ & \\
\hline $\begin{array}{r}1 \\
2 \\
3 \\
4 \\
5 \\
6 \\
7 \\
8 \\
9 \\
10 \\
11\end{array}$ & $\begin{array}{l}\because \\
\because \\
\because \\
\because \\
\because \\
\because \\
\because \\
\because\end{array}$ & $\begin{array}{l} \\
\because \\
\therefore \\
\because \\
\because \\
\cdots \\
\therefore \\
\therefore\end{array}$ & $\begin{array}{r}22 \\
11 \\
3 \\
3 \\
6 \\
8 \\
8 \\
10 \\
3 \\
3 \\
10\end{array}$ & $\begin{array}{r}23 \\
11 \\
3 \\
3 \\
6 \\
9 \\
10 \\
10 \\
3 \\
3 \\
11\end{array}$ & $\begin{array}{c}\text { No } \\
\text { Salm. johannesburg } \\
\text { Salm. thompson } \\
\text { No } \\
\text { No } \\
\text { Salm. thompson } \\
\text { Salm. thompson } \\
\text { Salm. thompson } \\
\text { Salm. thompson } \\
\text { No } \\
\text { No }\end{array}$ & $\begin{array}{r}29 \\
32 \\
6 \\
4 \\
12 \\
19 \\
18 \\
11 \\
5 \\
6 \\
25\end{array}$ & $\begin{array}{l}\text { Yes } \\
\text { Yes } \\
\text { Yes } \\
\text { Yes } \\
\text { Yes } \\
\text { Yes } \\
\text { Yes } \\
\text { Yes } \\
\text { Yes } \\
\text { Yes } \\
\text { Yes }\end{array}$ & $\begin{array}{l}\text { Yes } \\
\text { Yes } \\
\text { No } \\
\text { No } \\
\text { No } \\
\text { Yes } \\
\text { No } \\
\text { Yes } \\
\text { Yes } \\
\text { Yes } \\
\text { Yes }\end{array}$ & $\begin{array}{l}\text { Yes } \\
\text { No } \\
\text { Yes } \\
\text { Yes } \\
\text { Yes } \\
\text { Yes } \\
\text { Yes } \\
\text { No } \\
\text { Yes } \\
\text { Yes } \\
\text { No }\end{array}$ & $\begin{array}{l}\text { Yes } \\
\text { Yes } \\
\text { Yes } \\
\text { No } \\
\text { Yes } \\
\text { Yes } \\
\text { No } \\
\text { Yes } \\
\text { Yes } \\
\text { Yes } \\
\text { No }\end{array}$ & $\begin{array}{l}\text { Operative } \\
\text { Conservative } \\
\text { Conservative } \\
\text { Conservative } \\
\text { Operative } \\
\text { Conservative } \\
\text { Operative } \\
\text { Conservative } \\
\text { Conservative } \\
\text { Operative } \\
\text { Operative }\end{array}$ \\
\hline
\end{tabular}

Hypothermia occurred in eight of the cases during the first 24 hours. These were mainly those born "on district." This is an almost invariable finding in all our premature babies born "on district." Four were apnoeic and required resuscitation and two had mild respiratory distress (Table II). Five babies had jaundice with serum bilirubin levels above $10 \mathrm{mg} / 100 \mathrm{ml}$ in the first week; two required exchange transfusions-one on one occasion and one on two occasions (Table II).

TABLE II-Relevant Aspects of Neonatal Period

\begin{tabular}{|c|c|c|c|c|c|c|c|}
\hline Case & No. & $\begin{array}{c}\text { Birth } \\
\text { Weight } \\
\text { (g) }\end{array}$ & Apnoea & $\begin{array}{l}\text { Hypo- } \\
\text { thermia }\end{array}$ & $\begin{array}{l}\text { Respira- } \\
\text { tory } \\
\text { Distress }\end{array}$ & $\begin{array}{c}\text { Jaundice. } \\
\text { Bilirubin } \\
>10 \mathrm{mg} / 100 \mathrm{ml}\end{array}$ & $\begin{array}{l}\text { Exchange } \\
\text { Trans- } \\
\text { fusion }\end{array}$ \\
\hline $\begin{array}{l}1 \\
2 \\
3 \\
4 \\
5 \\
6 \\
7 \\
8 \\
9 \\
10\end{array}$ & $\begin{array}{l}\ldots \\
\cdots \\
\cdots \\
\cdots \\
\cdots \\
\cdots \\
\cdots\end{array}$ & $\begin{array}{l}1,210 \\
1,700 \\
1,660 \\
1,300 \\
1,900 \\
1,300 \\
1,590 \\
1,050 \\
1,260 \\
1,700\end{array}$ & $\begin{array}{l}\text { Yes } \\
\text { No } \\
\text { No } \\
\text { Yes } \\
\text { Yes } \\
\text { No } \\
\text { No } \\
\text { No } \\
\text { No } \\
\text { Yes }\end{array}$ & $\begin{array}{l}\text { Yes } \\
\text { No } \\
\text { Yes } \\
\text { Yes } \\
\text { Yes } \\
\text { Yes } \\
\text { No } \\
\text { Yes } \\
\text { Yes } \\
\text { No }\end{array}$ & $\begin{array}{l}\text { Mild } \\
\text { No } \\
\text { Mild } \\
\text { No } \\
\text { No } \\
\text { No } \\
\text { No } \\
\text { No } \\
\text { No } \\
\text { No }\end{array}$ & $\begin{array}{l}\text { Yes } \\
\text { No } \\
\text { Yes } \\
\text { No } \\
\text { Yes } \\
\text { No } \\
\text { No } \\
\text { No } \\
\text { Yes } \\
\text { Yes }\end{array}$ & \begin{tabular}{|c|} 
No \\
No \\
No \\
No \\
No \\
No \\
No \\
No \\
Yes: 3rd day \\
Yes: 3rd,
\end{tabular} \\
\hline 11 & .. & 1,600 & No & Yes & No & No & No \\
\hline
\end{tabular}

Diarrhoea occurred in every case. This began between 3 and 22 days of life and in every instance was severe enough to cause dehydration and require intravenous therapy. In all, diarrhoea clearly preceded the onset of necrotizing enterocolitis, the interval ranging from 1 to 21 days. Of the six cases with salmonellae, five had Salm. thompson and one Salm. johannesburg. One of these cases had an exchange transfusion (Table III).

The specific presentation consisted of abdominal distension which was invariable, bile-stained vomitus or gastric aspirate,

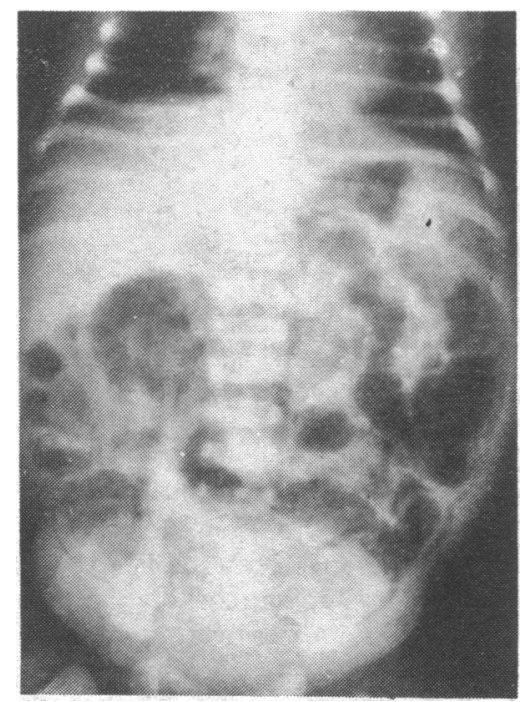

FIG. 1-X-ray film of abdomen showing extensive intramural gas of bowel. blood-stained stools, and oedema of the abdominal wall, which occurred in the majority (Table III). All showed evidence of peripheral circulatory failure.

Ten patients were radiographed, the remaining one having died very shortly after the clinical diagnosis was established. The 10 cases showed gross abdominal distension which was generally associated with fluid levels and intramural gas (Fig. 1), two showed intrahepatic gas, and one showed evidence of free gas in the peritoneum, indicating perforation of the bowel (Fig. 2) (Table IV). Platelet counts were carried out in eight, and

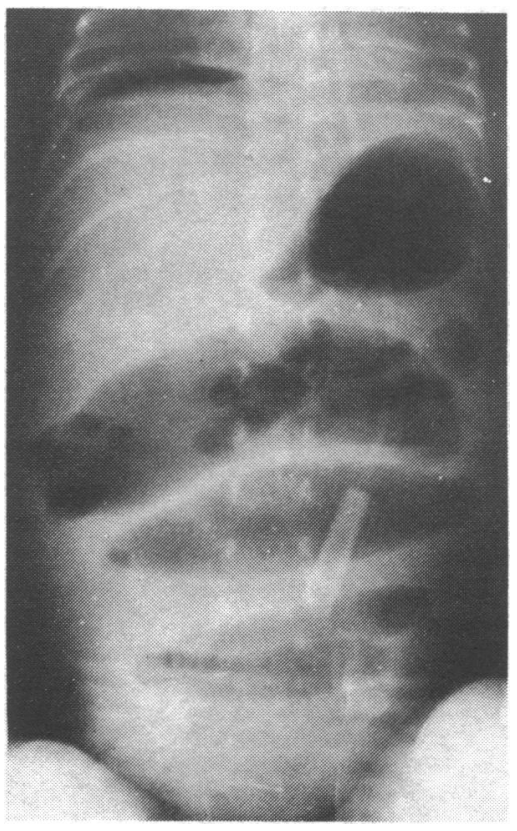

FIG. 2-X-ray film of abdomen showing free intraperitoneal gas present under dome of right diaphragm. Evidence of bowel distension and free intra-abdominal fluid is present. Perforation of bowel was verified at necropsy.

TABLE IV-X-ray Findings

\begin{tabular}{|c|c|c|c|c|c|c|}
\hline \multicolumn{2}{|c|}{$\begin{array}{l}\text { Case } \\
\text { No. }\end{array}$} & Distention & $\begin{array}{c}\text { Fluid } \\
\text { Levels }\end{array}$ & $\underset{\text { Gas }}{\text { Intramural }}$ & $\begin{array}{c}\text { Intrahepatic } \\
\text { Gas }\end{array}$ & Perforation \\
\hline $\begin{array}{l}1 \\
2 \\
3 \\
4 \\
5 \\
6 \\
7\end{array}$ & $\begin{array}{l}\ldots \\
\because \\
\because \\
\cdots\end{array}$ & $\begin{array}{l}\text { Yes } \\
\text { Yes } \\
\text { Yes } \\
\text { Yes } \\
\text { Yes } \\
\text { Yes } \\
\text { Yes }\end{array}$ & $\begin{array}{l}\text { Yes } \\
\text { Yes } \\
\text { Yes } \\
\text { Yes } \\
\text { Yes } \\
\text { Yes } \\
\text { No }\end{array}$ & $\begin{array}{l}\text { Yes } \\
\text { No } \\
\text { Yes } \\
\text { Yes } \\
\text { Yes } \\
\text { Yes } \\
\text { No }\end{array}$ & $\begin{array}{l}\text { No } \\
\text { Yes } \\
\text { No } \\
\text { No } \\
\text { No } \\
\text { No } \\
\text { No }\end{array}$ & $\begin{array}{l}\text { No } \\
\text { Yes } \\
\text { No } \\
\text { No } \\
\text { No } \\
\text { No } \\
\text { No }\end{array}$ \\
\hline $\begin{array}{r}9 \\
10 \\
11\end{array}$ & $\begin{array}{l}\because \\
\because \\
\end{array}$ & $\begin{array}{l}\text { Yes } \\
\text { Yes } \\
\text { Yes }\end{array}$ & $\begin{array}{l}\text { Yes } \\
\text { No } \\
\text { Yes }\end{array}$ & $\begin{array}{l}\text { Yes } \\
\text { Yes } \\
\text { No }\end{array}$ & $\begin{array}{l}\text { No } \\
\text { Yes } \\
\text { No }\end{array}$ & $\begin{array}{l}\text { No } \\
\text { No } \\
\text { No }\end{array}$ \\
\hline
\end{tabular}

seven of these had levels below $100,000 / \mathrm{mm}^{3}$. Prothrombin indices were low in six of the nine examined. More detailed coagulation studies were limited to three patients because of technical difficulties (Table V). These suggested additional evidence of deficiencies of coagulation. 
TABLE V-Haematological Investigations

\begin{tabular}{|c|c|c|c|c|}
\hline & & $\begin{array}{l}\text { Platelet } \\
\text { Count }\end{array}$ & $\begin{array}{l}\text { Prothrombin } \\
\text { Index }(\%)\end{array}$ & $\begin{array}{c}\text { Other Coagulation } \\
\text { Studies }\end{array}$ \\
\hline & : & $\begin{array}{c}\text { Not done } \\
75,000 \\
250,000 \\
55,000\end{array}$ & $\begin{array}{c}\text { Not done } \\
69 \\
69 \\
40\end{array}$ & \multirow{3}{*}{$\begin{array}{c}\text { Not done } \\
\text { Not done } \\
\text { Not done } \\
\text { Kaolin partial thromboplastin time 85,2s } \\
\text { (normal 40-60 s) } \\
\text { Fibrinogen degradation products } \\
80 \mathrm{\mu g} / \mathrm{ml} \text { (normal 4-10 } \mathrm{\mu g} / \mathrm{ml} \text { ) } \\
\text { Not done } \\
\text { Not done } \\
\text { Not done } \\
\text { Not done } \\
\text { Factor IX assay } 24 \% \text {. Factor X assay } 33 \% \\
\text { Not done }\end{array}$} \\
\hline 5 & & 25,000 & 37 & \\
\hline $\begin{array}{r}6 \\
7 \\
8 \\
9 \\
\end{array}$ & $\begin{array}{l}. \\
\because \\
\because \\
\therefore\end{array}$ & $\begin{array}{c}25,000 \\
\text { Not done } \\
\text { Not done } \\
80,000 \\
55,000 \\
25,000\end{array}$ & $\begin{array}{c}62 \\
46 \\
\text { Not done } \\
43 \\
40 \\
43\end{array}$ & \\
\hline
\end{tabular}

The mortality was $100 \%$. Treatment was conservative in six and consisted of intravenous therapy, gastric suction, and antibiotics (penicillin and kanamycin or gentamicin). The remaining five had laparotomies and bowel resections and proximal diversions by ileostomy. Primary anastomosis was avoided where possible. Biopsies were carried out in all the operated patients and necropsies on all those treated conservatively. In each case the characteristic findings of necrotizing enterocolitis were made macroscopically and histologically (Figs. 3, 4, and 5).

\section{Discussion}

A typical clinical pattern emerges from an analysis of these cases. All were premature babies. The majority had evidence of neonatal stress in terms of hypothermia, apnoea, respiratory distress, and jaundice, but the incidence was no different from that of those babies who were unaffected. It may well be,

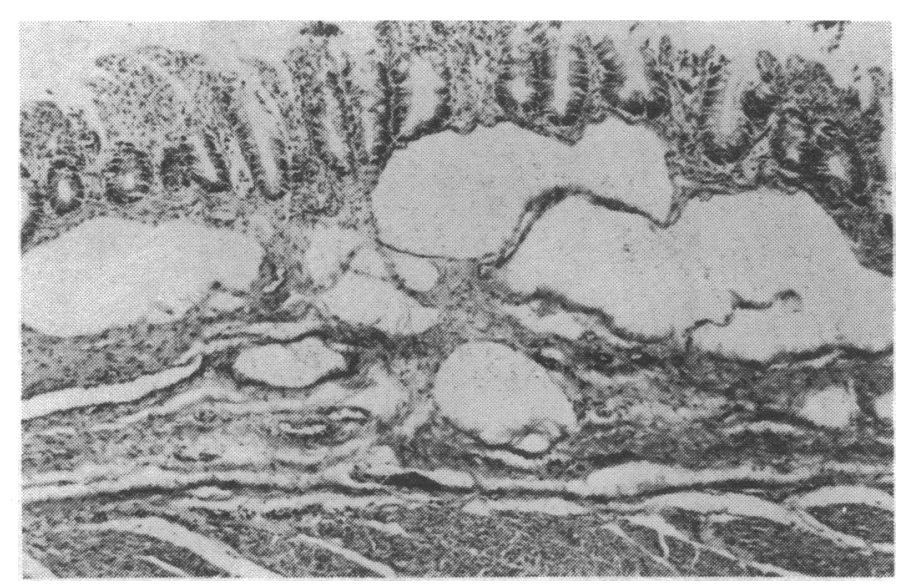

FIG. 3-Pneumatosis intestinalis showing intramural submucosal gas-filled spaces. (H. \& E. $\times 35$ ).

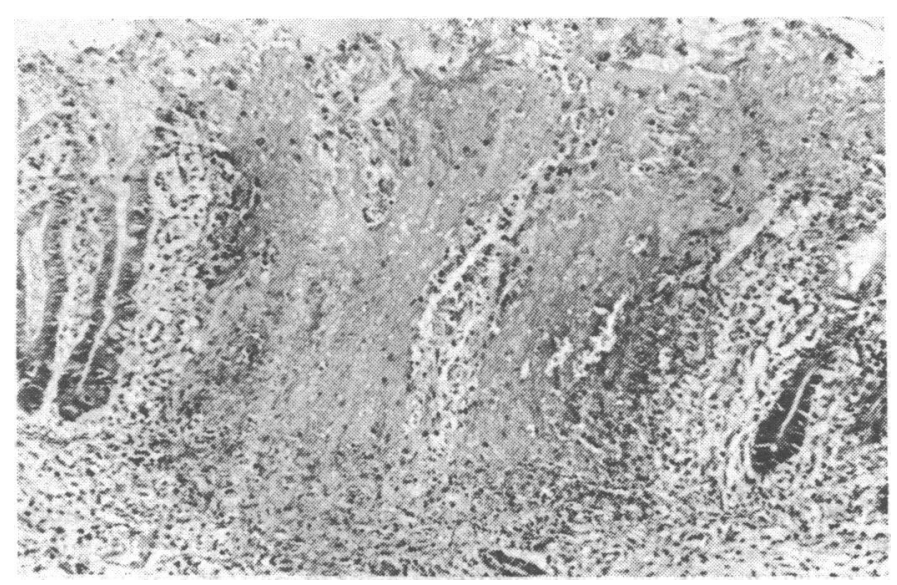

FIG. 4-Section of large bowel showing a focal area of mucosal necrosis (H. \& E. $\times$ 55.)

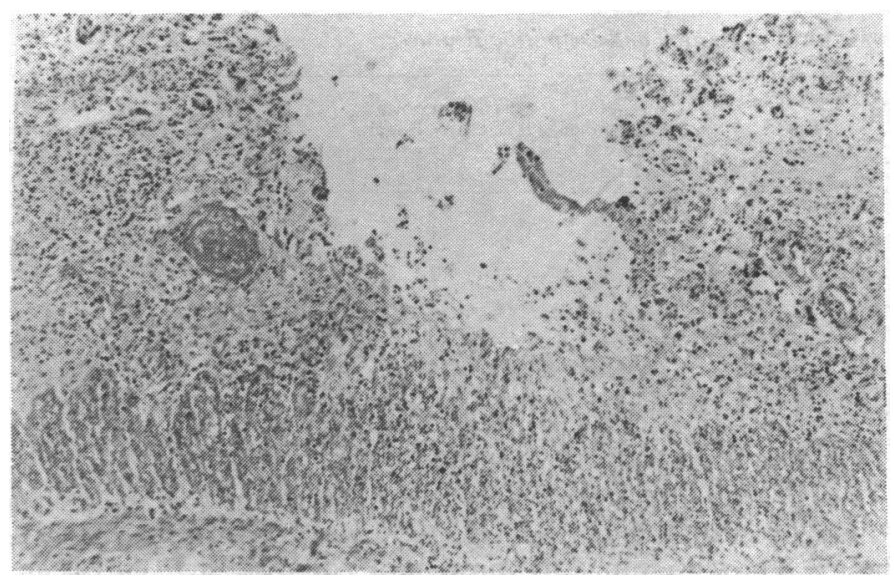

FIG. 5-Section of large bowel showing necrosis, ulceration, and a transmural inflammatory reaction. A thrombosed vein is present on left side of ulcer. (H. \& E. $\times$ 39.)

however, that the neonatal stress did make them more vulnerable to subsequent insults by causing an ischaemia of the bowel. Lloyd (1969) suggested that in newborn infants subjected to stress or hypoxia reflex redistribution of circulation may take place analogous to that occurring in the seal during prolonged submergence. Thus, as in the diving reflex of the seal, blood would be shunted away from organs less vulnerable to anoxia, such as the intestinal tract and kidneys, to the heart and brain.

In all the cases the common denominator was that of infective diarrhoea, and this was either the sole factor or the precipitating factor in the babies with an already devitalized intestinal mucosa. All affected cases then progressed, after a variable period, from the non-specific features of gastroenteritis to that of the specific picture of necrotizing enterocolitis.

These cases are very unusual in that gastroenteritis was common to all and salmonella was the infecting agent in more than half. The British Medical fournal (1970) has stated that frank diarrhoea is rare. Fetterman (1971) described a typical but hypothetical case of neonatal necrotizing enterocolitis. The patient was a premature infant who appeared lethargic and sick probably due to sepsis. He progressed to the fullblown clinical syndrome of necrotizing enterocolitis in which "the stool may be blood-stained but is usually not diarrhoeal."

Apart from the fact that diarrhoea as such is considered to be rare, and though most authors postulate the importance of infection (Willi, 1944; Waldhausen et al., 1963; Mizrahi et al., 1965; Touloukian et al., 1967; Wilson and Woolley, 1969) in neonatal necrotizing enterocolitis, the evidence for infection has generally not been well established. Blanc (1952) suggested that the swallowing of infected amniotic fluid by infants born to mothers with amnionitis might be significant. Waldhausen et al. (1963) recovered Pseudomonas aeruginosa from the abdominal cavity, blood stream, or stool in four out of six patients with this disease and felt that this might represent an aetiological agent. Fetterman (1971) stated that the search for a specific infectious agent had been fruitless. Mizrahi et al. (1965) suggested that the action of endotoxins of Gram-negative organisms contained in the intestinal tract may be an aetiological factor.

There seems little doubt about the significance of infection in the cases here described, but its exact role remains to be established; being a Gram-negative infection it may well support the view that a Shwartzman reaction is operative. Certainly, histological examination in some of the cases showed multiple small vein thromboses in addition to the necrosis (Fig. 6) and it was felt that these findings were consistent with a Shwartzman reaction. An attempt was made to establish the possibility of a Shwartzman reaction by doing coagulation studies. Platelet counts and prothrombin indices were abnormal in most but detailed coagulation studies were done in only a few.

It is difficult to determine the role of exchange transfusion in two of the patients. Certainly these two cases had infection as 


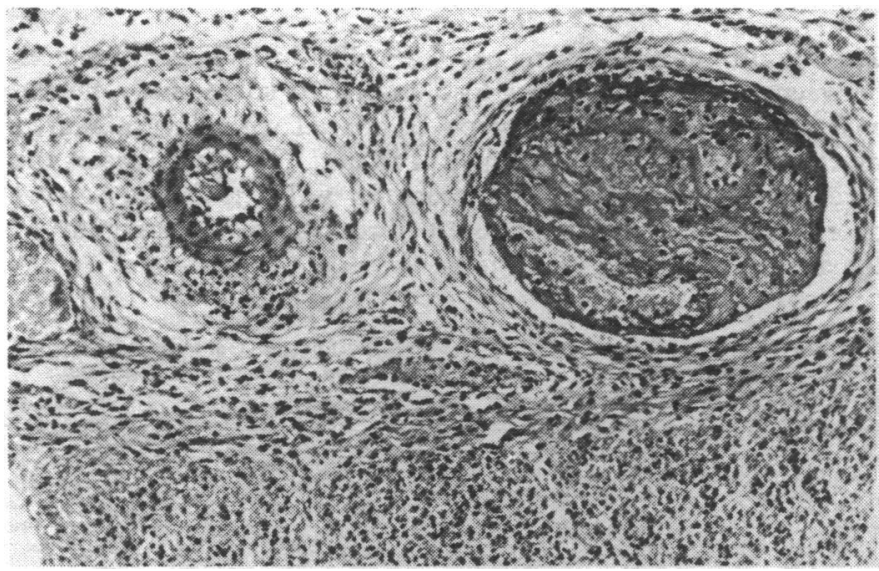

FIG. 6-Submucosal venous thrombosis with a mild infiammatory reaction. (H. \& E. $\times$ 87.)

well, though the onset of necrotizing enterocolitis followed more rapidly than in most cases. It is probable that exchange transfusion in association with infection were combined aetiological factors.

Although all diagnoses were confirmed radiologically and histologically, the cases form a homogeneous clinical group in which the antecedent history of prematurity and gastroenteritis and more specifically salmonella infection, progressing to the acute abdominal catastrophe, was so typical that there was no difficulty in making a firm diagnosis on clinical grounds.
Though necrotizing enterocolitis in premature babies remains a disease of multifactorial origin, this series lends strong support to the aetiological significance of infection.

We wish to thank Professor S. Wayburne and members of the Paediatric Staff for access to cases; the Superintendent of Baragwanath Hospital for permission to publish; the Director of the South African Institute for Medical Research for facilities granted; and Mr. M. Ulrich for photomicrographs.

\section{References}

Beck, J. M., Dinner, M., and Chappel, J. (1971). South African fournal of Surgery, 9, 39.

Berdon, W. E., et al. (1964). Radiology, 83, 879.

Blanc, W. A. (1952). Clinical Obstetrics and Gynecology, 2, 705.

British Medical Fournal, 1970, 3, 121.

Castor, W. R. (1968). Canadian Medical Association fournal, 99, 934

Corkery, J. J., Dubowitz, V., Lister, J., and Moosa, A. (1968). British Medical fournal, 4,345

Fetterman, G. H. (1971). Pediatrics, 48, 345.

Hermann, R. E. (1965). Surgery, 58, 436.

Lloyd, J. R. (1969). Fournal of Pediatric Surgery, 4, 77.

Mizrahi, A., Barlow, O., Berdon, W., Blanc, W. A., and Silverman, W. A. (1965). Journal of Pediatrics, 66, 697.

Orme, R. L., and Eades, S. M. (1968). British Medical fournal, 4, 349.

Rossier, A., Sarrut, S., and Delplanque, J. (1959). Semaine des Hopitaux Paris, 35, 1428.

Stevenson, J. K., Graham, C. B., Oliver, T. K., and Goldenberg, V. E. (1969). American fournal of Surgery, 118, 260.

Touloukian, R. J., Berdon, W. E., Amoury, R. A., and Santulli, T. V. (1967) fournal of Pediatric Surgery, 2, 389.

Waldhausen, J. A., Herendeen, T., and King, H. (1963). Surgery, 54, 365. Willi, H. von (1944). Annales de Pédiatrie, 162, 87.

Wilson, S. E., and Woolley, M. M. (1969). Archives of Surgery, 99, 563.

\title{
Comparison of Subjective Estimates by Surgeons and Anaesthetists of Operative Blood Loss
}

\author{
A. E. DELILKAN
}

British Medical fournal, 1972, 2, 619-621

\section{Summary}

Altogether 100 cases were studied to compare the subjective estimates of operative blood loss by anaesthetists (six in number) and by surgeons (22 in number). Their estimates were compared with the blood loss measured by a colorimetric method, which was assumed to be the operative blood loss. The results showed that surgeons are less reliable judges of operative blood loss then anaesthetists. When objective measurement of operative blood loss is impracticable the anaesthetist and the surgeon should jointly make a subjective estimation.

\section{Introduction}

Operative blood loss can be estimated subjectively (by the anaesthetist or the surgeon), but this method is universally accepted as unreliable. There are many objective methods such as the gravimetric method (Wangensteen, 1942), various colorimetric methods (Gatch and Little, 1924; Endahl and

\footnotetext{
Department of Anaesthesiology, University of Malaya, Kuala Lumpur, Malaysia

A. E. DELILKAN, M.B., B.S., F.F.A. R.C.S., Senior Lecturer
}

Moller, 1952; Rustard, 1963), the electric conductivity method (LeVeen and Rubricius, 1958), and isotopic direct methods with the Volemetron (Williams and Fine, 1961). Even the objective methods have an error in estimation but this is usually significantly less than that of the subjective methods and thus more acceptable clinically.

In most hospitals in this part of the world it is often not possible to use the more sophisticated objective methods for estimating operative blood loss routinely for two reasonsfirstly, because such facilities do not exist and, secondly, because operative schedules are usually pressed for time. The operative blood loss is thus measured either by the gravimetric method or by some colorimetric method (where facilities exist) only in the more major cases where a large blood loss is expected. In most other situations the subjective estimation is used. This sometimes leads to a difference of views between the surgeon and the anaesthetist.

The purpose of this paper is to try to evaluate which of the two, the surgeon or the anaesthetist, is the more unreliable in estimating operative blood loss, a colorimetric method being used as the constant for comparison.

\section{Patients and Method}

Altogether 100 cases were studied during July to December 1969 at the University Hospital, Kuala Lumpur. The patients (51 males, 49 females) were aged 10-87 (mean 43.9) years and 